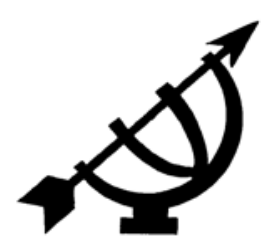

\title{
Can Calvin provide a golden thread in the labyrinth of catechisms available in the church today?
}

\author{
J. Janse van Rensburg \& L. Hoffman \\ Department of Practical Theology \\ University of the Free State \\ BLOEMFONTEIN \\ E-mail: jjvanr@yebo.co.za \\ hoffmanl.hum@ufs.ac.za
}

\begin{abstract}
Can Calvin provide a golden thread in the labyrinth of catechisms available in the church today?

A congregation can easily get lost in the labyrinth of catechism syllabi available for an educational ministry today. Calvin's wish was that the church would have one catechism common to all churches. However, he consented to different churches developing different catechisms. He also warned about the power of catechesis, as it has the potential to influence the church for decades to come, and as the body of Christ can be strengthened or wounded through catechesis. Can Calvin provide a golden thread to navigate the labyrinth of catechisms available in the church today? Different models of catechesis are discussed briefly. The similarities and differences with Calvin's approach to catechism are highlighted, and the article concludes with guidelines for contemporary catechesis.
\end{abstract}

\section{Opsomming}

Kan Calvyn 'n goue draad voorsien in die doolhof van beskikbare kategismusse in die kerk vandag?

'n Gemeente kan maklik verdwaal in die doolhof van kategesesillabusse wat vandag vir opvoedkundige bediening beskikbaar is. Dit was Calvyn se wens dat kerke een gemeenskaplike kategismus gebruik. Hy het egter toegegee dat verskillende kerke tog verskillende kategismusse kon ontwikkel. Hy het ook gewaarsku dat die krag van kategese oor die potensiaal beskik om die kerk in die volgende dekades te beïnvloed. Die liggaam 
van Christus kan versterk of gewond word deur kategese. Kan 'n goue draad vanuit Calvyn se kategismus afgelei word waarmee die doolhof van kategesemateriaal vandag genavigeer word? Verskillende kategesemodelle wat tans beskikbaar is, word kortliks bespreek. Die ooreenkomste en verskille met Calvyn se benadering tot kategese word uitgelig. Ten slotte word riglyne vir huidige kategese gestel.

\section{Introduction and methodology}

The aim of this article is to analyse some of John Calvin's basic assumptions for catechesis against the backdrop of current theoretical and practical problems with catechesis in churches all over the world. 1 Therefore, it operates from a practical theological epistemology. Different denominations use different terms for their "educational ministry". For the purpose of this article, the term catechesis will serve as a synonym and substitute for other concepts like Sunday School, covenant teaching and educational ministry and will be used to refer to the official work of the church in the formation of faith of children and the youth.

Both Calvin's first and second catechisms will be explored in the present research, even though the second catechism substituted the first in a way. In the introduction to his second catechism, Calvin gives preference to the latter, although the motivation seems to be that, would he not have written the second and the first would disappear, nothing would be left that could be used for catechesis (Calvin, 1997; 2006). Besides the obvious value of the first as a brief summary of the Institutes (Hesselink, 1997:42), many important principles revealing Calvin's understanding of catechesis could be identified, helping us to revisit our own approach. Besides, both introductions complement each other in helping us to understand Calvin's basic assumptions about catechesis.

\section{Statement of the problem}

There could be little argument about the great dilemma of catechesis today. There are so many different points of view on catechesis (for example Drury \& Drury, 2004; Modkats, s.a.; Osmer, 1990; Veldsman, 2005; Venter \& Van der Merwe, 2005), and cur-

1 It is significant and noteworthy to see how many scientific articles and papers at conferences and on websites deal with the problem of renewal in catechism (e.g. Gowins, 2007; Heyns, 1994; Prins, 1993). The older dates show for how long the struggle with regard to catechesis has been with us. 
rently this important part of the mission of the Christian church is bordered by two extremes. While some have turned catechesis into nothing more than a youth action with little or no education, reducing it to Christian activities like missionary work, others have opted for models of catechesis where the emphasis is on socialisation rather than on education (Gowins, 2007).

It seems as though attendance of catechesis is decreasing. Strumpfe (2008:3) states that attendance of catechesis in the Dutch Reformed Church (DRC) congregations in South Africa has decreased from $60 \%$ to $40 \%$ per year. Opinions on what catechesis should be differ widely, and some ministers simply write their own material for catechesis according to their own convictions. In many ways, these tendencies could be initiated or influenced by the paradigm shift ${ }^{2}$ where the tendency is to move away from a deductive approach in knowledge and reasoning to an inductive approach in spirituality and experience. Of course, both should be equally important in catechesis. In the latest official handbooks for catechesis of the DRC, efforts were made to accommodate both. However, in general, the preference seems to be with experience more than with knowledge. Could we learn something from John Calvin's approach to catechesis to solve the dilemma? In the following paragraphs, the contemporary catechesis landscape is sketched, likening it to a labyrinth. In search of a golden thread in this labyrinth, a brief comparison is made between Calvin's approach and contemporary practice in catechesis. In conclusion, some principles for contemporary catechesis are drawn from Calvin's work.

\section{Contemporary catechesis}

Looking over the landscape of catechesis, the image of a labyrinth comes to the fore. A labyrinth is a delineation of space to facilitate wandering around some object placed at the centre. There is more than one way to get into and out of a labyrinth (Hall, s.a.). In ancient times, many myths were told about labyrinths. In the famous myth of the labyrinth outside Athens, princess Ariadne gave a golden yarn to prince Theseus to help him find his way in the labyrinth. Can a golden thread be provided for churches today, helping them navigate the labyrinth of material available for catechesis?

2 Prins (1997) analyses some implications of the paradigm shift for catechesis. 
Catechesis is practised in different ways in the church today. Searching under the theme "Sunday school models" produces 596 results with Google. In Bloemfontein, referring to only the ten DRC congregations, at least five different models for catechesis are used. In 1997, the General Youth Commission (GYC) of the DRC decided that more than one model may be used in the DRC because of the ever-increasing diversity. Figure 1 illustrates a move away from the "official curriculum" of the GYC for junior and senior catechesis (Bischoff \& Schoeman, 2006). Interestingly enough, there has been an increase in the use of GYC material for confirmation classes. From Figure 2, it is clear that more DRC congregations not using GYC material make use of other published material rather than writing their own material.

Fig. 1: Use of "official" curriculum for catechesis

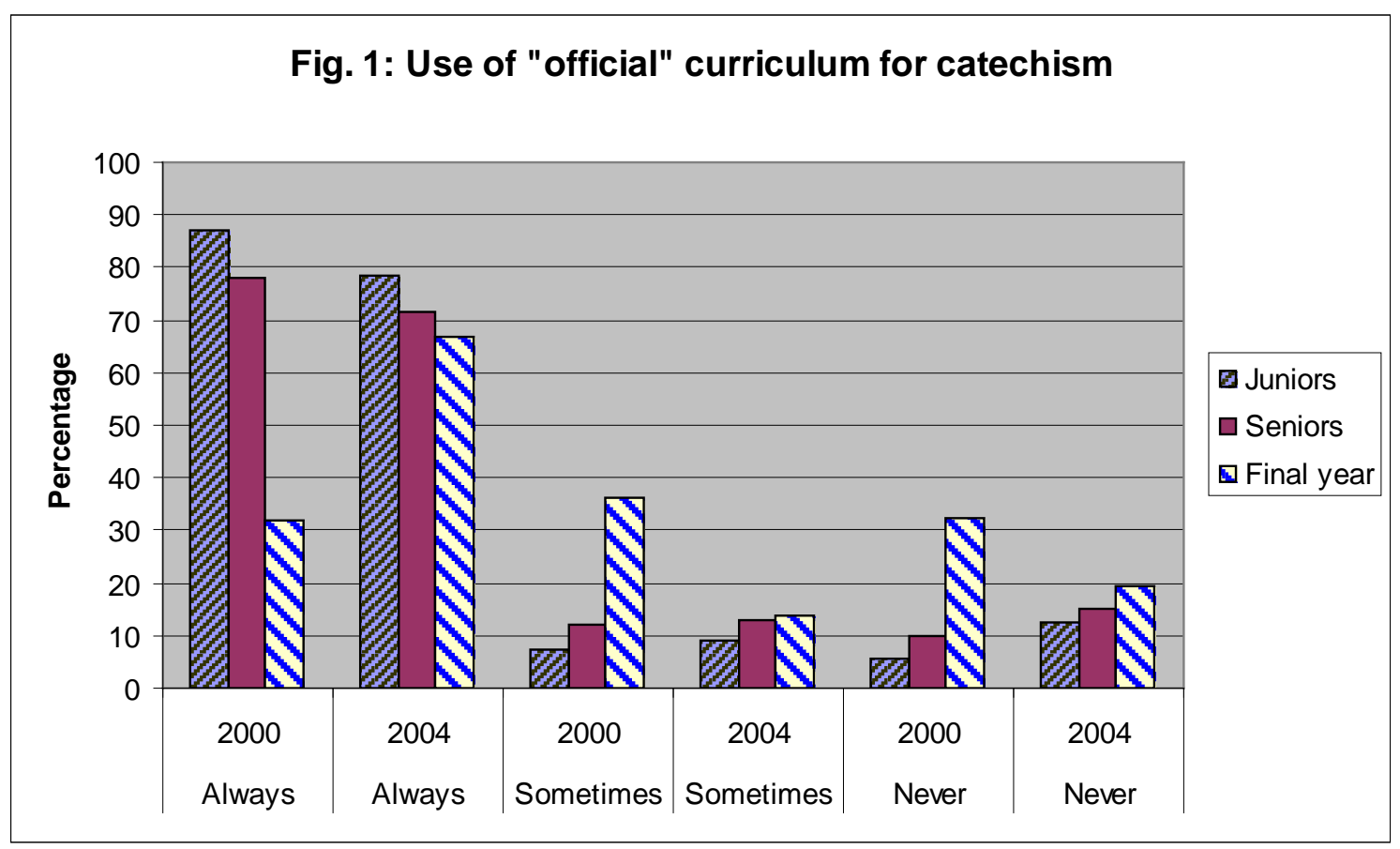

Material presently used in different congregations and denominations includes the following:

- Modkats (a modular approach to catechesis)

- Official curriculum of the General Youth Commission (GYC) of the DRC

- Evangelism expansion (EE3) 
- The three particular confessions of faith (Heidelberg Catechism, Canons of Dordt, Belgic Confession)

- Bible knowledge programmes

- Online catechesis material

- A variety of catechesis programmes are also found in different Christian denominations

Fig. 2: Use of "non-official" curricula for catechesis

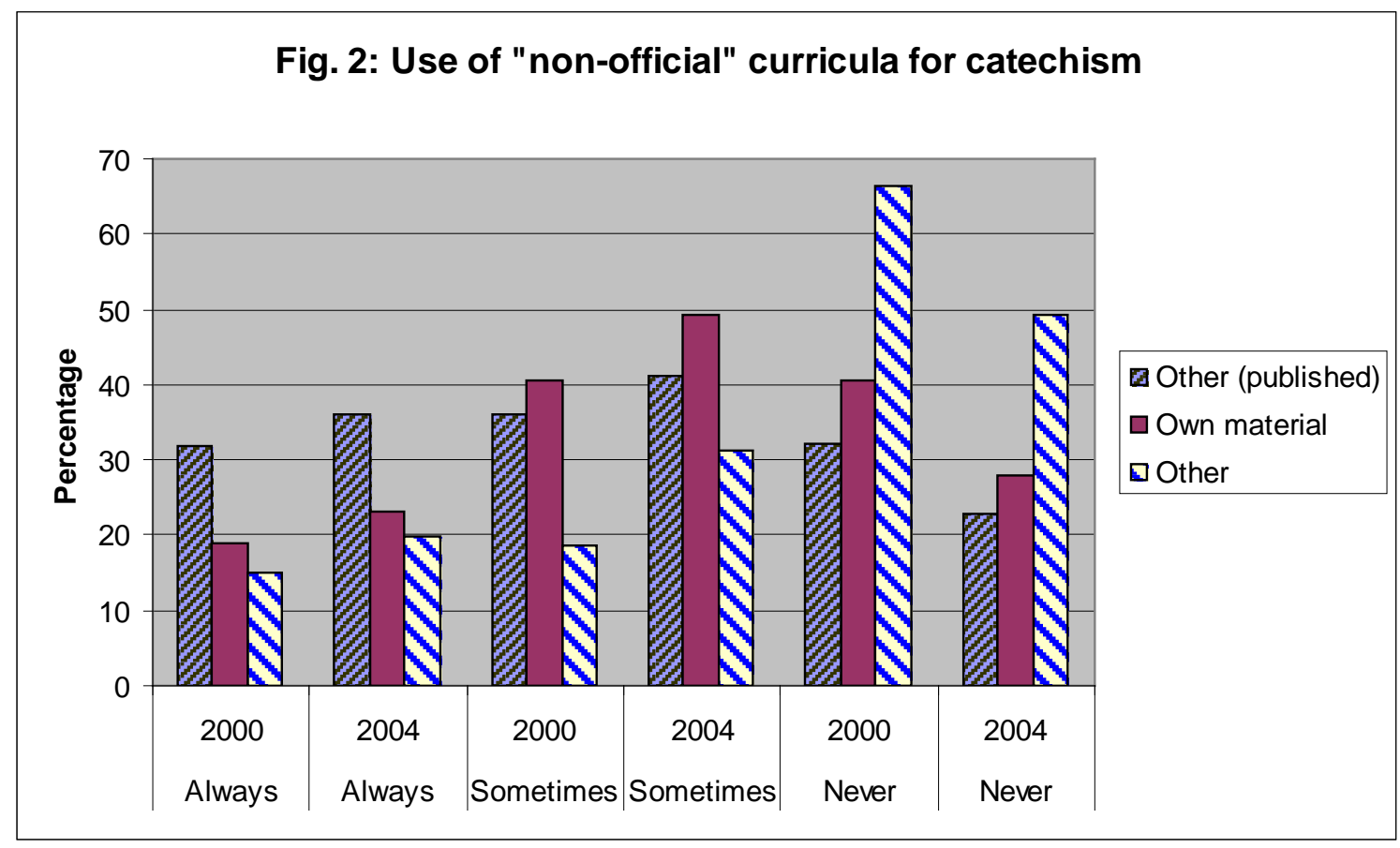

In view of the above, it does seem that different approaches to catechesis are all wandering towards the "object in the centre", which seems to be the development of faith in Jesus Christ as the Saviour. What does the labyrinth of current approaches to catechesis look like? A few of the possible routes into the labyrinth will be discussed briefly.

\subsection{Modkats}

Currently 225 DRC congregations are using Modkats (Modkats, s.a.). Modkats is a modular approach to catechesis within the following framework: faith formation involves four aspects, namely (Biblical) knowledge, commitment, relationships and mystery. Biblical content forms an important part of faith formation. It centres around truth, choices, skills, knowledge and application. Children and the 
youth must make a commitment to Jesus Christ, the kingdom of God, the body of Christ, disciplines and to themselves. Faith formation has to do with relationships: acceptance, belonging, connecting, support and journeying together. The mysterious aspect of faith refers to seeking answers to the mysteries in the lives of children and young people, and helping one another to interpret the incomprehensible. The goal of catechesis in this approach is to further the understanding of being Spirit-filled, having a sense of being called by God and being passionate about serving God. Furthermore, the context/world in which faith formation takes place, spiritual and emotional needs of the youth as well as the practical realities regarding faith formation should be considered. From this brief list, it becomes abundantly clear that the emphasis in Modkats is far more on the need for understanding life and experience than on teaching church dogmas. The shift from a deductive to an inductive approach is apparent.

The following outcomes for the curriculum have been identified: The child/young person must have a relationship with Jesus Christ, know about grace, practise spiritual discipline (e.g. Bible study), live a morally responsible life and accept his/her responsibility in the congregation. Furthermore, they must demonstrate love, accept responsibility and authority, be positive/hopeful, participate in the congregation and be of service. This corresponds with Calvin's emphasis on the believer's responsibility to arrange his/her whole life according to God's law (Osmer, 1990:108).

\subsection{Curriculum of the General Youth Commission (GYC)}

In this approach, material for catechesis is written with the following principles in mind (Angus et.al., 2002:6 ff.):

- Every class meeting should be a real encounter between the child/young person and God.

- The meeting must also be between the teacher and the children and the children among themselves. Thus, the term lesson should be replaced with meeting.

- The Bible must be central in each meeting.

- Even when doctrine is the theme in the catechesis, the child/ young person must discover that the foundation of it all is still the Bible. 
- The child/young person must learn about Christ and his immeasurable grace.

- The forms of unity will also be used in catechesis. The child/ young person must develop a love for the truths that can be confessed on the foundation of the Bible.

- Children/young people must discover how their relationship with the Lord affects their daily lives.

- Faith values must be discovered and practised.

- It is not a one-way communication. Group discussions must also be stimulated. Children/young people must experience that they and their teacher are learning together as truths in the Bible and confessions are discovered. The teacher must share personal experiences, thus modelling his/her faith.

- Catechesis must connect the child/young person with the congregation. It must open their eyes for service opportunities in the congregation, motivating and equipping them for service.

- Children/young people must be supported in the development of a faithful prayer life and Bible study.

- Conversation between parent and child must also be stimulated. Parents and children must be empowered to share their faith. Here, the covenantal point of departure, so strongly emphasised by Calvin, is operative.

Considering Calvin, the above principles incorporates the important role of parents in developing their children's faith. However, in both Modkats and the GYC-curriculum, the question remains whether the "bigger picture" of the church as the one body of Christ (over all ages and even denominations) is addressed appropriately. Catechesis is not aimed at the children/young people of a particular congregation just for the sake of that congregation, but with a view to the whole body of Christ (cf. Calvin, 2006 [1545]).

\subsection{Other models for catechesis}

Veldsman (2005) promotes a familial perspective on catechesis. This entails that faith formation is seen as a continuing process, involving believing parents, the bigger family, the children and youth organisations in the church, small groups and Bible study groups.

Some congregations also use a series by Rick Warren on The purpose driven life in their catechesis. Drury and Drury (2004) points 
out that Warren lays out how to define and display "our relationship with God, his people, and his purpose in our future". The book is intergenerational, a structure for life and belief and may be seen as a unifying doctrine among evangelists. In this regard, it corresponds with Calvin's ideal to unify as many churches as possible in catechesis. However, the long-term value of such an approach is doubtful. The following significant remark is made:

The purpose driven life will one day become a mere snapshot of a passing phase in a particular Christian community's life. ... Sooner or later, The purpose driven life will no longer look like a compendium of simple, timeless truths, but rather will exhibit how time-bound its 'truth' really was ... (Drury \& Drury, 2004). 3

A plethora of material for catechesis is also available on the worldwide web. One website states, "It's a good idea to look at your own denominational beliefs but if it does not fill your needs, keep looking ..." Another claims that you can prepare for Sunday school in less than 5 minutes ... "Finally, no more having to think of fun, creative crafts or activities - l've done the hard part, you just follow the plan step by step. The kids LOVE these lesson plans ..." An American church invites, "How would you like to go to an exciting Sunday school class every Sunday?" The "Abundant Life Sunday School" (Sunday school, 2004) sets its goal to help churches achieve its purpose by:

- leading people into a committed relationship with Christ and his church;

- disciplining Christians in their faith;

- involving Christians in a ministry of the church;

- enjoying themselves and having fun;

- meeting friends;

- gaining knowledge;

- discovering answers;

- creating a better life for themselves;

3 One can only speculate what is meant by "time bound truths". Could this be the ghost of postmodern relativism of truth or does it refer only to the contextual changes brought about by time? 
- finding a sense of purpose;

- exploring God's Word for truth;

- gaining acceptance;

- encountering God!

\subsection{The danger of the labyrinth in catechesis}

Calvin warns in the 1545 Catechism of Geneva,

Wherefore, those who publish Catechisms ought to be the more carefully on their guard. By producing anything rashly, they may not for the present day only, but in regard to posterity also, do grievous harm to piety, and inflict a deadly wound on the Church.

Producing material for catechesis is a great responsibility.

Calvin ends the prologue to his 1538 Catechism with these words: "Therefore, let all our care, watchfulness, industry, attention press toward this edification, which we know will succeed to the degree that it advances in sober fear of God, sincere piety, and unfeigned holiness of morals." Catechesis that aims only at making the experience as enjoyable as possible may miss this aspect of diligently striving to please God.

Among others, the dangers of a labyrinth are that the traveller can easily get lost, losing sight of "the object in the middle", have a limited sense of progression and have difficulty in evaluating different pathways available, while progressing in the wrong direction.

Evaluating the brief summary of a variety of models discussed above, the following dangers could be outlined:

- Ineffective faith formation could result in children not being prepared adequately for the challenges of life.

- Focusing on favourite topics of the presenter.

- Forgetting the unity of all believers, thinking only of the faith formation of the individual.

- Focusing so much on presentation or outcomes, that good Biblical and doctrinal content is compromised.

- Meeting only the "wants" of the children (experience, etc.) and not fulfilling their deep spiritual needs could result in a one-sided 
emphasis on life, resulting in neglecting a true spirituality. Calvin's emphasis on piety is extremely important in this regard.

- Not giving enough attention to the choice of teacher could lead to a breakdown in communication, a lack of spiritual influence and a degrading of catechesis into pleasurable socialisation.

- Adopting catechesis material from different theological points of departure could send contradictory messages to children, confusing their perceptions of the message of the Bible. In this regard, we particularly think of Calvin' reformed approach of sola gratia in contrast to the emphasis on man's own choices and decisions (Pelagianism) in the teachings of some denominations.

\section{A brief comparison with Calvin's approach to catechesis}

When aiming to compare Calvin's approach with contemporary catechesis, the differing times should be considered first. Furthermore, the use of God's Word, unity in the church and the covenant seem to be important themes in this comparison.

\subsection{Different times complicate comparisons}

Simply reinstituting Calvin's Catechism in our postmodern age would not be answering the challenges of catechesis today. In so many ways, our postmodern age is different from the life and times of Calvin. ${ }^{4}$ From the introduction to his first Catechism (1538), we can clearly see that the purpose of his endeavour is to defend the truth of the Christian faith against all kinds of heresy opposing the gospel of salvation, "to strengthen the consciences by teaching things that are true, sure, and profitable" (Calvin, 1964 [1559]:1.14.4). Therefore, it is understandable that the character of this first Catechism is very intellectual and difficult to follow. For edifying children (then and today), it would simply not suffice. This, in fact, was Calvin's reason for changing his approach in the second Catechism of 1542 (Calvin, 1542), presenting the material in questions and answers.

Today, however, many churches have abandoned even the question and answer method because it is again perceived to be too scholarly and too difficult for children in the postmodern context. This approach can only be lamented, considering how difficult the school

4 See the discussion on the historical background by Hesselink (1997:39-43). 
material is that children have to deal with. Could it be that the fear of children not wanting to attend catechism if there is too much emphasis on edification was responsible for this change in approach? It seems as though we allow children to live in two worlds. In school, they are introduced to the world of modernism, science, facts and learning. In catechesis, however, they are allowed to socialise, play, listen to music and have topical discussions (cf. Fox, 2008:8). Prins (1993:87) argues that the current overemphasis on personal experience in catechesis could be the result of a too strong emphasis on the cognitive (knowledge of doctrine) in the past (cf. Venter \& Van der Merwe, 2005:115).

Or does this have something to do with the fact that the church has adopted the postmodern approach of "We don't really know" and "No one has all the answers", contrary to Calvin's motivation to educate in things that are true, sure and profitable? Do we need such a reinstatement of education in the truth? Without a shadow of a doubt! In this regard, Calvin could already help us out of our dilemma in catechesis. We will simply have to find ways and means to unite the two extremes of a deductive approach in education and an inductive approach in experience. The latter is important in the context of Calvin's own spirituality shining through both editions of his Catechism. 5

About this spirituality, Hesselink (1997:43) writes, "Calvin was also a person of deep feeling and warm personal faith. He was a profoundly religious man whose piety (godliness) shines through the pages (of the Catechism)." Therefore, catechesis should never be about knowledge only. It is knowledge leading to salvation (Hesselink, 1997:73). Prins (1993:85) correctly points to the unity between the cognitive and the affective in the Catechism of the Reformation. Perhaps this might be one of the greatest disadvantages in the more recent past of catechesis, namely that an overemphasis was placed on the scholarly learning of dogma and too little room was left for internalising these facts. In this regard, we must again be reminded of the operative expression at the beginning of the introduction to the second Catechism, where Calvin writes about "a perpetual consent in the doctrine of piety". In this phrase, the deductive and the inductive are united.

5 See for example sections 1-3 of his first Catechism. 


\subsection{God's Word should still be the point of departure}

The remark above on the different times between then and now is of great importance when considering the basis for catechesis today. Calvin is clear on the issue that education is not about exchanging your own ideas "but to dispense things taken soberly and faithfully from God's pure Word" (Calvin, 1997 [1538]: Introduction). Noteworthy is the operative word pure in this quotation. It is common knowledge that Calvin accepted the Bible as God's true and reliable Word although, strangely enough, he does not deal with the character of the Bible as Word of God in his Catechism of 1538. 6 However, both catechisms are noted for their constant reference to the Bible as the source of different teachings, some with many Scriptural references.

In his day, this was a common conviction among all churches and there would be no argument about it. However, matters are quite different today. All over the world, churches no longer agree on the status of the Bible as the infallible Word of God (cf. Nuwe Hervorming, s.a.; Tiefling, 2003). On the other hand, there is still a large contingent of ministers requesting that the Bible should feature even more. Since the latter group is currently in the majority, Calvin's emphasis on Scripture as the basis for catechesis should be pursued bravely. Indeed, it could be said that this was the greatest and most urgent need for edification, since more and more members and children of the congregation know very little about God's Word. It seems as though catechesis is continually caught up in extremes, since there are also ministers who wish to see catechesis simply as Bible study. Important as this may be, per definition, Bible study could not qualify as catechesis.

\subsection{Unity in catechesis}

Calvin's clear intention was to seek unity in faith through his Catechism. He hoped that it would be made available to other churches in order that "they may become more certain of our union with them" (Calvin, 1997 [1538]). This ideal for unity is reiterated in the second Catechism, where Calvin longs for consent on the doctrine of piety, thus leading to the express hope "that one catechism was common to all the churches".

6 For a discussion on this omission, see Hesselink (1997:54-56). 
Calvin was greatly concerned about the "wicked denunciation" of opposition against the gospel, which is so effective in dividing the minds of otherwise good men and uprooting churches. In this regard, he was of the opinion that it is much more effective to stop such adversities before they become effective rather than to wait until the minds of people have been poisoned by false charges against the church. Calvin was indeed extremely worried about the future of the church and what would happen to the children if the true teachings of the gospel would no longer prevail. 7 Against the backdrop of such a threat, about which Calvin expressed the hope that "our children may not shortly feel that this has been rather a true prophecy than a conjecture", Calvin motivated the need for unity in faith through catechesis.

The great onslaught against the Christian faith concerning the doctrines of faith, of which Calvin wrote in strong phrases, finds unmistakable similarities with the challenges the church is facing today. Therefore, it is a matter of urgency to work towards a catechism that will be conducive to furthering the unity of the Christian faith and unite the church in its stand against the postmodern onslaught of relativism.

This does not mean that basic denominational diversity should or could be ignored. Calvin was realistic enough to acknowledge that such complete unity would scarcely be possible (Calvin, 2006 [1545]). However, denominational traditions should be subservient to the greater need of upholding the true teachings of faith. Needless to say, this should be pursued with great care not to sacrifice any aspect of the truth that Calvin so vigilantly sought. In the unification process of the four reformed churches of the DRC family, this unity is indispensable and it should be strengthened by including all churches of the reformed faith in South Africa. Of course, other churches that are willing to co-operate should be included. Furthermore, at least within one given church, there should be general agreement on the most basic premises of the true faith in order to prevent the critical inclination of the world to smile on the disagreement among Christians on matters of faith. 8 Therefore, the

7 "Unless God miraculously send help from heaven, I cannot avoid seeing that the world is threatened with the extremity of barbarism."

8 Calvin agrees that we cannot prevent different churches from writing their own teaching material "provided, however, that the variety in the mode of teaching is such that we are all directed to one Christ, in whose truth, being united together, 
current tendency of ministers writing their own material for catechesis should not be supported or encouraged.

\subsection{God's covenant as backbone of catechism}

Three reasons for the importance of the covenant in catechism can be deduced from Calvin's work. In his introduction to the Catechism of 1538, Calvin made out a strong case for the covenant as the theological driving force or ground motive for catechesis. Referring to the covenants that Josiah, Ezra and Nehemiah made with God on behalf of the people, he argues that such a covenant constrains men to be under God's command, obliged to obey God's law. Covenant and law are one. Yet, unable to fulfil the law, we are offered God's grace through the righteousness of Jesus Christ (Calvin, 1997 [1538]: Article 16). However, this does not mean an attitude of indifference towards the law, for the same Holy Spirit who binds us to Christ's righteousness, also binds us to his sanctification. "Because he covenants with us in Christ", God offers his kindness towards our weaknesses, yet inspires us through his Holy Spirit to seek obedience to the law, acting as "a lantern for our feet to keep us from wandering away from the straight path".

This covenantal approach is a much-needed point of departure in catechesis, particularly within the context of the influence of postmodernity on people's obsession with freedom. Let us be honest and realistic. This is precisely how the postmodern man/ woman sees himself/herself. No longer are they willing to be told how to live and what not to do. God's law is no longer of any interest. It is also not considered to be "a lantern" (Ps. 119:105) to prevent us from being led astray. Teenage sex, extramarital affairs and other transgressions of God's law have become the order of the day among members of God's church. Adolescents are probably sniggering at the church when during catechesis it is suggested that such conduct is against God's law. Perhaps it is precisely this fear of being rejected or the possibility that adolescents might refrain from coming to catechesis that causes teachers to refrain from ethical directions.

Should such an attitude simply be accepted? Should we in catechesis be even more diligent in driving home the responsibility of

we may grow up into one body and one spirit, and with the same mouth also proclaim whatever belongs to the sum of faith". 
sanctification after justification? ${ }^{9}$ The church will have to attend to ministers who have no theological insight into this matter because how will ministers be allowed to teach sanctification in catechesis if they themselves have no passion for such a teaching?

If they only had the knowledge of Calvin's clear explanation of the relation between law and gospel and the indispensable link of the covenant, thereby justifying instruction in the law of God! In his discussion of the creed (Calvin, 1997 [1538]: Article 20) and in the discussion of believing in the Holy Spirit, Calvin emphasised the important work of the Spirit, illuminating us to recognise "the enormous wealth of divine goodness we possess in Christ". This divine wealth becomes the motivation to see Christian freedom as willingness to accept that God has the authority to set his law as a guide to a godfearing life. In his second Catechism, the question about the preface to the law is answered as follows: "To remind us that we will be guilty of the greatest ingratitude if we do not devote ourselves entirely to obedience to him." Hesselink (1997:92) explains Calvin's intentions in more detail:

Christian are free, not from the abiding meaning of the law, but from the rigid requirements, curse, and consequent burden of the law. The special office of the Spirit is to mold and remake them according to the image of God. The Spirit does this by means of the law, which is no longer an external accusing power but a helpful friend implanted in their being.

Furthermore, the covenant as point of departure for catechesis is important for a second reason. In his first Catechism, Calvin placed more emphasis on the responsibility of parents to instruct children, while in the second Catechism the responsibility of the church and its officials is emphasised. Van 't Veer (1942:44) is of the opinion that this should not be interpreted as though the latter substitutes the former. Today, the role of parents has become just as important (if not more so) than in Calvin's day. The joint responsibility of the church, school and parents regarding catechesis that Calvin so strongly emphasised $\mathbf{1 0}$ no longer exists in a secular state.

Thirdly, the lack of understanding and honouring the covenantal promises is probably the main reason why children show such poor

9 Cf. Calvin's radical explanation of the seventh commandment in his second Catechism (Calvin, 2006 [1545]). 
knowledge of the Scripture. Helping parents to understand the covenant could motivate them once again to take up their responsibility to be involved in their children's catechesis. John Calvin did not directly include Scripture teaching in his Catechism because he placed the responsibility for such education squarely on the shoulders of the parents (Van 't Veer 1942:174). However, how able are parents to teach their children the Word of God, should we succeed in making them willing? If we could but return to the practice in Geneva when Calvin expected parents to attend catechism classes (Van 't Veer 1942:171)! 11

\section{Some principles for contemporary catechesis}

Congregations that want to navigate the labyrinth of catechesis available today can take hold of the golden thread found in Calvin's Catechism. Among others, it entails the following:

\subsection{The aim of catechesis}

In the first place, catechesis is not an evangelisation tool. It is about edification of the believer through knowledge of God and the Bible (Calvin, 1542). The curriculum followed in a congregation should state emphatically that its aim is to edify the believer. This does not rule out the use of catechesis as an opportunity to convert children/ young people. However, using catechesis material with content that focuses mainly on converting children/young people will not be balanced enough to build up their faith. Children attending catechesis are members of the covenant community. As such, the focus should be on the religious potential of the covenant child, realising their faith through catechesis (Venter \& Van der Merwe, 2005:115).

\subsection{Structuring content}

True to the character of all Calvin's work, he sets the example of organising his catechetical material, one item building upon the other. A particular question leads to a specific answer, making the next question seem obvious. Thus, there is an overall systematic structure (Zachman, 2006:135). This leads us to conclude that true catechism could never be constituted where material is incorporated in a haphazard fashion into a loose ensemble of interesting themes, without having a firm and well structured foundation.

11 Adendorf (1995) based the theme of his dissertation on the education of the parents. 
There should be a balance between God-centred catechesis and applying the principles of such a faith to the everyday challenges of a person's life, finding rest only in God (Calvin's 1538 Catechism, Article 2). In the first place, catechesis is not only about acquiring life skills. It is not only about knowing and understanding the best way to live, but about knowing and understanding the language of faith (the Apostolic creed, the celebration of the sacraments, etc.). In the second Catechism, Calvin's instruction on the relation between faith and the work of the Holy Spirit suggests that the Spirit creates a faith experience that amounts to the understanding of things that we would otherwise not comprehend. On the other hand, catechesis is not only about gaining knowledge, but also about being equipped to apply God's law in everyday situations (cf. Venter \& Van der Merwe, 2005:129). Learning Bible verses only without discussing how their content can be practised, is letting go of the golden thread that would lead us through the labyrinth.

\subsection{Involving parents}

We need to find ways and means of successfully engaging parents in catechesis, motivating them to take up their covenantal responsibilities. Parents must be equipped to fulfil their special role in providing not only spiritual guidance to their children, but also in encouraging the acquisition of Biblical knowledge (cf. Zachman, 2006:135). Material used in catechesis should facilitate parental participation. This could be in the form of prescribed activities for parents and children, discussion classes that parents also attend, and letters to parents informing them of the content and aim of that year's catechesis classes.

\subsection{Catechesis and the unity of believers}

Catechesis must always be seen within the "big picture" - the worldwide, century-spanning body of Christ. Church unity should be made easier because of catechesis. We must "with the same mouth also proclaim whatever belongs to the sum of faith" (Calvin, 2006 [1545]). This golden thread should caution congregations not to decide on the content of catechesis without taking other congregations (and their own tradition of faith) into consideration. The curriculum followed in catechesis should represent a balanced content, reflecting the tradition of faith in that church. Thus, children/young people moving to other congregations will not feel lost when moving to a new catechesis school. They will experience that they are part of the body of Christ, sharing the main themes of faith presented in 
catechesis. Therefore, catechesis should not represent only the pet topics of a specific congregation/pastor.

\section{Conclusion}

Although we do not suggest a reinstatement of Calvin's Catechism for our postmodern times, we have argued that Calvin's approach to catechesis supplies us with the golden thread of basic principles without which we would not be able to find our way through the labyrinth of so many models and approaches. Without this golden thread, catechesis in our day would be without merit and remain inefficient.

\section{List of references}

ADENDORFF, J.A.E. 1995. Kerklike bediening aan verbondsouers met die oog op verbondsonderrig aan hulle kinders. Bloemfontein: Universiteit van die Vrystaat. (Ongepubliseede doktorale tesis.)

ANGUS, G., CLASSEN, J. \& CRONJE, H. 2002. Handboek vir die kategeet, Graad 8. Bloemfontein: Christelike Lektuurfonds (CLF).

BISCHOFF, J. \& SCHOEMAN, W.J. 2006. Kerkspieël. (Ongepubliseerde verslag.)

CALVIN, J. 1542. Le Catéchisme de l'église de Genéve c'est a dire le formulaire d'instruire les enfants en la chrestienté. (CO 6,1-134.)

CALVIN, J. 1863-1900 [1531-1564]. Ioannis Calvini Opera Quae Supersunt Omnia, Vol. I-LIX. 1863-1900. Ediderunt G[W]. Baum, E. Cunitz \& E. Reuss. Vol. I-LIX, in Corpus Reformatorum, Vol. XXIX-LXXXVII. Brunsvigae/Berolini: C.A. Schwetschke et filium. [= CO 1-59.]

CALVIN, J. 1964 [1559]. Institutes of the Christian religion. Trans. by $\mathrm{H}$. Beveridge. Grand Rapids: Eerdmans.

CALVIN, J. 1997 [1538]. Catechism. Trans. by F.L. Battles. Louiseville: Westminster John Knox.

CALVIN, J. 2006 [1545]. The Geneva Catechism. http://www.reformed.org/ documents Date of access: 20 Jul. 2008.

$\mathrm{CO}$

see CALVIN, J. 1863-1900 [1531-1564]

DRURY, D. \& DRURY, J. 2004. "Purpose driven catechism": is the purpose driven life the evangelical catechism? http://www.drurywriting.com/david/ PurposeDrivenCatechism.htm Date of access: 25 Aug. 2008.

FOX, K. 2008. Postmodern pew fillers: keeping children's ministry in sync with emerging generations. http://www.milligan.edu/academics/writing/pdfs/ fox.pdf Date of access: 20 May 2009.

GOWINS, R.A. 2007. How to double your Sunday school class. http://www.inglewoodbaptistchurch.org/clientimages/33890/howtodoubleyo ursundayschoolclass.pdf Date of access: 28 Aug. 2008.

HALL, D. S.a. Into the labarynth. http://labyrinth.donavanhall.net/ Date of access: 20 Aug. 2008.

HESSELINK, J. 1997. Calvin's first Catechism. Louisville: Westminister John Knox. 
HEYNS, L.M. 1994. Geloofsonderrig en die toekoms. Praktiese teologie in Suid Afrika, 9(2):155-164.

MODKATS. s.a. Modkats: 'n styl van geloofsvorming vir 'n post-moderne generasie. http://www.modkats.co.za/ Datum van gebruik: 20 Aug. 2008.

NUWE HERVORMING. s.a. Nuwe Hervorming netwerk: ons waardes. http://www.nuwe-hervorming.org.za/wiki/welkom-nuwe-webwerf-nuwehervorming-netwerk Datum van gebruik: 6 Mei 2009.

OSMER, R.R. 1990. A teachable spirit: recovering the teaching office in the church. Louisville: Westminster John Knox.

PRINS, J.M.G. 1991. Kategese en geloofsoordrag deur sosialisering. Nederduitse Gereformeerde Teologiese Tydskrif, 32(2):250-259.

PRINS, J.M.G. 1993. Vertrekpunte en riglyne vir vernuwing van die kategese. Nederduitse Gereformeerde Teologiese Tydskrif, 34(1):81-91.

PRINS, J.M.G. 1997. Postmoderniteit en jeugbediening: enkele aspekte van 'n paradigmaverskuiwing en die implikasies daarvan vir die kerklike jeugbediening. Praktiese teologie in Suid-Afrika, 12(2):38-60.

STRUMPFE, W. 2008. Die nuwe uitdagings vir geloofsvorming van kinders en jongmense. Jonk E-tydskrif: 3, Nov. http://www.jeugfokus.org.za/ etydskrifte/JonkNovember.htm Datum van gebruik: 6 Mei 2009.

SUNDAY SCHOOL 2004. Sunday school ... learning to live the life. http:// sundayschool.ag.org/Articles/20040113_modelss.cfm Date of access: 28 Aug. 2008.

TIEFLING 2003. Moderate Christianity. http://everything2.com/title/Moderate\% 2520 Christianity Date of access: 8 May 2009.

VAN 'T VEER, M.B. 1942. Catechese en catechetische stof bij Calvijn. Kampen: Kok.

VELDSMAN, H.J. 2005. Geloofsvorming vanuit 'n familiale perspektief. Pretoria: Unisa. (Ongepubliseerde M.-verhandeling.)

VENTER, C.J.H. \& VAN DER MERWE, C.N. 2005. Die verwerkliking van die geloof in die kerklike kategese: basisteoretiese perspektiewe. Acta theologica, 25(1):112-133.

ZACHMAN, R.C. 2006. John Calvin as teacher, pastor and theologian. Grand Rapids: Baker.

\section{Kernbegrippe:}

Calvyn

Christelike opvoeding

kategese

kategismus

\section{Key concepts:}

Calvin

catechesis

catechism

Christian education 
